\title{
Anticoagulant Therapy in Primary and Secondary Recurrent Pregnancy Losses with Hereditary Thrombophilia and Perinatal Outcomes
}

\author{
Hatice Işıkl', Hüsnü Alptekin ${ }^{1}$, Refika Selimoglul, Türkan Cengiz'l, Hasibe Uygun Küçükapan², Nazife Alptekin ${ }^{2}$
}

\begin{abstract}
ABSTARCT
Objective: To investigate the effect of anticoagulant treatment and perinatal outcomes in patients with primary or secondary recurrent pregnancy loss without cause other than inherited trombophilia.

Methods: A total of 143 pregnant patients with recurrent pregnancy loss ( $\geq 2$ abortus) and had no detected cause other than thrombophilia, were included in the study. Patients with no livebirth history were accepted as primary and patients with at least one livebirth were as secondary recurrent spontaneous aborters (PrimRSAs and SecRSAs). Inherited thrombophilia genetic results of the patients in both groups were compared. The effects of low-molecular weight heparin (LMWH) and low-dose aspirin (LDA) treatments alone or together, livebirth rates and pregnancy outcomes were investigated.
\end{abstract}

Results: Sixty-eight patients were in PrimRSAs and 75 were in SecRSAs. Ages, numbers of total, early and late pregnancy loss of both groups were similar. In PrimRSAs 49 (72.1\%) and in SecRSAs 50 (66.6\%) patients had three or more inherited thrombophilia genetic mutations. Of 113 patients who used LMWH+LDA during pregnancy 88 (77.6\%) had livebirth; however, of 19 patients who used LMWH 6 (31.6\%) and of 11 women who used LDA 8 (72.7\%) had livebirth. Livebirth rate was significantly higher in patients who used LMWH+LDA together $(p=0.001)$. Livebirth rates were higher in SecRSAs than PrimRSAs irrespective to the anticoagulant treatment $(p=0.002)$.

Conclusion: LMWH and LDA treatment together may increase livebirth rates in patients with recurrent pregnancy loss and inherited thrombophilia. Having at least one livebirth of the patients is a good prognostic factor. J Clin Exp Invest 2016; 7 (1): 29-34

Key words: Recurrent pregnancy loss, anticoagulant treatment, inherited thrombophilia

\section{Kalıtsal Trombofilili Primer ve Sekonder Tekrarlayan Gebelik Kayıplarında Antikoagulan Tedavi ve Gebelik Sonuçları}

\section{ÖZET}

Amaç: Kalıtsal trombofili dışında neden saptanmayan primer ve sekonder tekrarlayan gebelik kaybı olan hastalarda antikoagulan tedavinin etkinliğini ve gebelik sonuçlarını araştırmak

Yöntemler: Çalışmaya tekrarlayan gebelik kaybı (iki veya daha fazla) nedeni ile takip edilen ve kalıtsal trombofili dışında neden saptanmayan toplam 143 gebe hasta alındı. Hiç canlı doğumu öyküsü olmayan hastalar primer, en az bir defa canlı doğumu olan hastalar sekonder tekrarlayan spontan abortu yapan olarak kabul edildi (PrimRSA ve SecRSA). Her iki gruptaki hastaların kalıtsal trombofili genetik sonuçları karşılaştırıldı. Düşük molekül ağırlıklı heparin (LMWH), düşük doz aspirin (DDA) tedavilerinin yalıı başlarına veya birlikte kullanıldıklarında her iki grupta canlı doğum oranları ve gebelik sonuçları üzerine etkileri araştırıldı.

Bulgular: 68 hasta primer, 75 hasta sekonder tekrarlayan spontan abortus grubunda idi. Her iki grubun yaş, toplam gebelik kaybı, erken ve geç gebelik kaybı sayıları benzer bulundu. Primer grupta 49 hastada $(\% 72,1)$, sekonder grupta ise 50 hastada $(\% 66,6) 3$ veya daha fazla kalıtsal trombofili genetik mutasyonu saptandı. LMWH ve DDA'i birlikte kullanan 113 $(\% 79,1)$ hastanın 88'i $(\% 77,6)$ canlı doğum yaptı; halbuki yalnızca LMWH kullanan 19 (\%13,2) hastadan 6'sı (\%31,6), yalnızca DDA kullanan $11(\% 7,7)$ hastadan 8'i $(\% 72,7)$ canlı doğum sahibi oldu. Canlı doğum oranı LMWH+DDA kullananlarda anlamlı şekilde yüksek bulundu $(p=0,001)$. SecRSA grubunda antikoagulan tedavi modalitesinden bağımsız olarak canlı doğum oranları PrimRSA grubundakilere göre daha yüksekti $(p=0,002)$.

Sonuç: LMWH ve DDA tedavisi birlikte kullanılması, kalıtsal trombofili nedeni ile tekrarlayan gebelik kaybı yaşayan hastalarda canlı doğum oranlarını artırabilir. Hastaların daha önce en az bir sağlıklı doğum gerçekleştirmiş olması iyi bir prognostik faktördür.

Anahtar kelimeler: Tekrarlayan gebelik kaybı, antikoagulan tedavi, kalıtsal trombofili

${ }^{1}$ Mevlana University Faculty of Medicine, Department of Obstetrics and Gynecology, Konya, Turkey

${ }^{2}$ Mevlana University Faculty of Medicine, Department of Pediatrics, Konya, Turkey

Correspondence: Hatice Işık,

Mevlana University Faculty of Medicine, Department of Obstetrics and Gynecology, Konya, Turkey Email: k.hgonbe@gmail.com Received: 06.02.2016, Accepted: 17.03.2016

Copyright (C) JCEI / Journal of Clinical and Experimental Investigations 2016, All rights reserved 


\section{INTRODUCTION}

Recurrent pregnancy loss (RPL), accounts $1-2 \%$ of all pregnancies and an important problem among women of reproductive age [1]. The American College of Obstetrician and Gynecologists, describes RPL as two or more sequential miscarriage [2]. Most common reasons for RPL are genetic and anatomic abnormalities, endocrine diseases, thrombophilia, and immunologic disorders. However, the etiology of approximately half of the recurrent pregnancy losses is still unknown.

Pregnancy is a hypercoagulable state which alters the coagulation factors. Factor VII, VIII, X, Von Willebrand factor activity, fibrinogen, protrombin (Factor II) and thrombin-antithrombin (TAT) complexes, plasminogen activator inhibitor type 1 (PAI-1) levels placentally-derived plasminogen activator inhibitor type 2 (PAI-2) are increased [3]. Anticoagulant activity is reduced including reduced protein $\mathrm{S}$ levels and acquired activated protein $\mathrm{C}$ resistance [4]. The studies have reported that inherited thrombophilia is related with pregnancy complications $[5,6]$ However, up to date there is conflict on the power of association. Inadequate placental perfusion due to a hemostatic imbalance is the main cause of obstetric complications [7]. Factor V Leiden (FVL), prothrombin (PT G202I0A), methylenetetrahydrofolate reductase C677T, and A1298 mutations (MTHFR), as well as protein $\mathrm{C}$, protein $\mathrm{S}$, and antithrombin III deficiencies are the most common causes of hereditary thrombophilia. Acquired thrombophilia is due to the presence of antiphospholipid antibodies, such as lupus anticoagulant and anticardiolipin antibody [8].

Sufficient utero-placental circulation is important for successful pregnancy outcomes since obstruction in placental vessels may cause recurrent miscarriages [7]. Although the effectiveness of anticoagulant prophylaxis is controversial, it is widely used in pregnants especially with poor obstetric histories.

In the present study we aimed to focus on the role of anticoagulant therapy in pregnant patients with histories of RPL and had no cause for RPL other than inherited thrombophilia. In addition, we aimed to detect the effect of anticoagulant therapy on pregnancy complications and on perinatal outcomes.

\section{METHODS}

A total of 9500 pregnant women who admitted to obstetrics outpatient clinics were reviewed in this retrospective study. The study was conducted in a university hospital between July 2015- February 2016. The study was approved by the Institutional Review Board in the exempt category. The inclusion criteria of the study group of 143 pregnant women were : pregnant women $>18$ years of age, a history of 2 or more consecutive losses with no other systemic illness, (parenteral ) normal genetic analysis, absence of uterine anomaly, no sign of urogenital infection. Hypertensive, diabetic, women with thyroid function disorders, women with coagulation defects, who had a history of deep vein thrombosis, or pulmonary thromboembolism were excluded.

Obstetric history and number of recurrent aborts of the patients were taken from medical records, whether the previous miscarriages occurred in the first or second trimester or whether they were biochemical pregnancy losses were noted. Biochemical pregnancy loss was used for the pregnancy loss which was diagnosed only with the decreasing beta form of human chorionic gonadotropin ( $\beta$-hCG) but no sign of pregnancy in the ultrasonography. Early pregnant loss was used for the abortions in the first trimester and late pregnancy loss for the losses in between $13-20^{\text {th }}$ gestational ages [2]. Pregnants were classified as primary and secondary aborters. Primary recurrent spontaneous aborters (PrimRSA) are women who had no live birth but two or more recurrent aborts. Secondary recurrent spontaneous aborters (SecRSA) are women who had at least one live birth and at least two aborts [9]. Uterus were assessed for Mullerian canal abnormalities which may cause RPL.

\section{Laboratory testing}

Protein C, protein S, Antithrombin (AT) activities were measured with chromogenix assays (Baxter Dade, Bonnstrasse, Switzerland). Protein C level of $75-135 \%$, protein $\mathrm{S}$ levels between 65 and 135\% and antithrombin levels $75-125 \%$ were defined as normal. Hereditary thrombophilia genetic tests were performed for FVL (G1691A), FII (A20210G), PAI1 4G/5G, MTHFR (C677T and A1298C) and FXIII. A Maxwell ${ }^{\circledR} 16$ System Blood DNA Purification Kit (Promega Corp, Madison, WI, USA) was utilized to extract genomic DNA from EDTA-anticoagulated whole blood samples. Real-time polymerase chain reaction (PCR) conducted in a LightCycler ${ }^{\circledR} 480$ Instrument (Roche Applied Science, Mannheim, Germany) was used to determine thrombophilic genotypes other than PAI-1. PAI-1 4G/5G I/D was assayed using "allele-specific amplification". Paternal karyotyping or the chromosomal analysis of the abort materials were recorded. 


\section{Treatment regimens}

Patients' anticoagulant treatment modalities were recorded. Patients who had received anticoagulant prophylaxis took low-molecular-weight heparin (LMWH, $100 \mathrm{IU} / \mathrm{kg}$, subcutaneous/day) or low-dose aspirin (LDA), $80 \mathrm{mg} /$ day. Subcutaneous injection of LMWH was administered by the patient itself, after instruction, to the skin of the abdomen once pregnancy was diagnosed.

\section{Outcome analysis}

All participants were closely followed up in the pregnancy period. First ultrasonography was performed at 6 weeks of pregnancy, and subsequently at routine antenatal follow-up at 4-weekly intervals. If a pregnancy loss had occurred, the karyotype analysis was performed. LDA was abandoned at week 36 of gestation, but enoxaparin was continued until the first signs of labor.

\section{Statistical analysis}

Statistical analyses were performed using the SPSS ver. 18.0 software (SPSS Inc, Chicago, Illinois). Distribution of data was determined by the KolmogorovSmirnov test. Continuous variables were expressed as means \pm standard deviations or medians (minimummaximum), and categorical variables as frequencies and percentages. Continuous variables were compared by Mann-Whitney U test, and categorical variables using Pearson chi-square test. $\mathrm{p}<0,05$ was considered to indicate statistical significance for all tests.

\section{RESULTS}

Of the total reviewed 9500 pregnants only $143(1.5 \%)$ patients with the history of RPL and genetic thrombophilia fulfilled the inclusion criteria and were studied. The demographic characteristics of the patients were given in Table 1. Of the patients 68 were PrimRSA and 75 were SecRSA (at least one live birth). The median ages of SecRSAs and PrimRSAs were similar [ 30 $(18-40)$ and $29(18-42)$ respectively, $\mathrm{P}=0.09)]$. There were no statistical difference between numbers of total pregnancy loss, early and late pregnancy loss in PrimRSAs and SecRSAs $(\mathrm{P}=0.539, \mathrm{P}=0.273, \mathrm{P}=0.857$ respectively). The median numbers of total pregnancy loss were 2 both in PrimRSAs and SecRSAs. Of the pregnancy losses in PrimRSAs 42 (61.8\%) had two or more early pregnancy loss, whereas only 3 (4.4\%) had two late pregnancy loss. In SecRSAs the median num- ber of live birth was 1 (1-3). Of the pregnancy losses in SecRSAs 55 (73.3\%) had two or more abortions in early pregnancy, $5(6.7 \%)$ had recurrent pregnancy loss in the second trimester. In the PrimRSA group 19 (27.9\%) patients had one or two genetic mutations and $49(72.1 \%)$ had 3 or more mutations. In the SecRSAs $2(2.7 \%)$ had no, $23(30.7 \%)$ had one or two and 50 (66.6\%) patients experienced three or more genetic mutations of thrombophilia tests. Protein C, Protein S and Anti-thrombin III levels were within the normal limits. There were no differences between the frequencies of genetic abnormalities between PrimRSA and SecRSAs except PAI homozygous was more frequent in SecRSAs (Table 1).

Table 1. Characteristic properties of women with primary and secondary recurrent abortus

\begin{tabular}{|c|c|c|c|}
\hline Variables & $\begin{array}{c}\text { PrimRSAs } \\
(n=68)\end{array}$ & $\begin{array}{c}\text { SecRSAs } \\
(n=75)\end{array}$ & $\begin{array}{c}p \\
\text { value }\end{array}$ \\
\hline Age & $29(19-42)$ & $30(18-40)$ & $0.091^{*}$ \\
\hline Live birth number & - & $1(1-3)$ & - \\
\hline Total pregnancy loss & $2(2-7)$ & $2(2-11)$ & $0.539^{*}$ \\
\hline \multicolumn{4}{|l|}{ Early pregnancy loss, n (\%) } \\
\hline$<2$ & $26(38.2)$ & $20(26.7)$ & \multirow{2}{*}{0.139} \\
\hline$\geq 2$ & $42(61.8)$ & $55(73.3)$ & \\
\hline \multicolumn{4}{|l|}{ Late pregnancy loss, n (\%) } \\
\hline$<2$ & $65(95.6)$ & $70(93.3)$ & \multirow{2}{*}{0.558} \\
\hline$\geq 2$ & $3(4.4)$ & $5(6.7)$ & \\
\hline \multicolumn{3}{|l|}{ Thrombophilia genetic mutation } & \multirow{3}{*}{0.485} \\
\hline$<3$ & $19(27.9)$ & $25(33.4)$ & \\
\hline$\geq 3$ & $49(72.1)$ & $50(66.6)$ & \\
\hline FVL homozygous & 0 & 0 & \\
\hline FVL heterozygous & $14(20.6)$ & $14(18.7)$ & 0.772 \\
\hline FII(A20210G) homozygous & 0 & 0 & \\
\hline FII (A20210G) heterozygous & $4(5.9)$ & $5(6.7)$ & \multirow[t]{3}{*}{0.847} \\
\hline MTHFR C677T homozygous & $7(10.3)$ & $11(14.7)$ & \\
\hline MTHFR C677T heterozygous & $28(41.2)$ & $32(42.7)$ & \\
\hline MTHFR 1298 homozygous & $12(17.6)$ & $6(8)$ & 0.076 \\
\hline MTFR 1298 heterozygous & $35(51.4)$ & $44(58.7)$ & 0.442 \\
\hline PAI homozygous & $8(11.8)$ & $24(32)$ & 0.004 \\
\hline PAI heterozygous & $44(64.7)$ & $41(54.7)$ & 0.222 \\
\hline FXIII homozygous & 0 & $1(1.3)$ & 0.341 \\
\hline FXIII heterozygous & $12(17.6)$ & $9(12)$ & 0.243 \\
\hline
\end{tabular}

The results were given as $\mathrm{n}(\%)$. FVL: factor $\mathrm{V}$ Leiden, MTHFR: methylenetetrahydrofolate reductase, PAI: plasminogen activator inhibitor * Mann-Whitney $U$ test. Chi-squared test was used to compare the categorical values. 


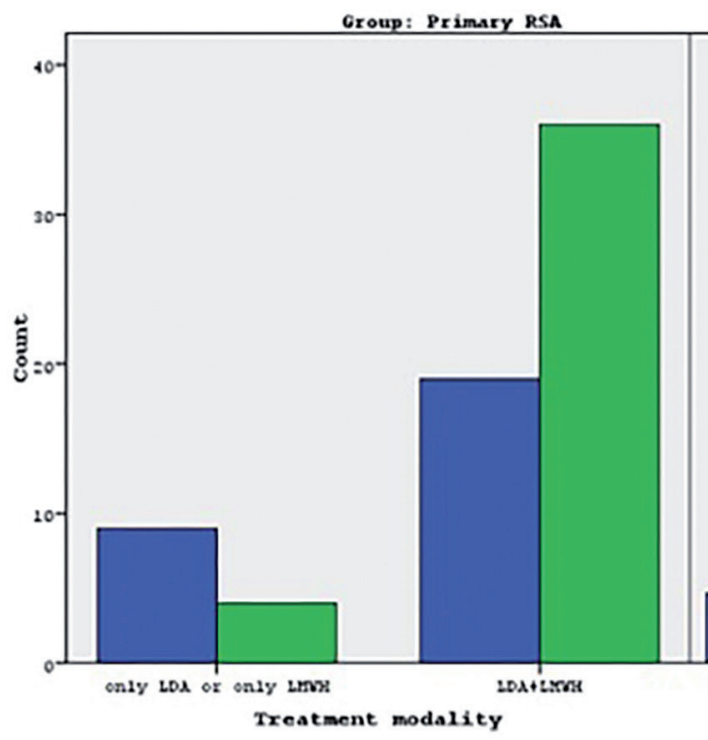

\section{Tromboprophylaxis during pregnancy and pregnancy outcomes}

During pregnancy $113(79.1 \%)$ of patients took LDA+LMWH, 19 (13.2) took only LMWH and 11 $(7.7 \%)$ had only LDA treatment. Pregnancy outcomes of the patients classified according to the treatment were given in Table 2. Of the patients in LDA+LMWH group $88(77.6 \%)$ of the patients had healthy live-birth, $25(22.4 \%)$ pregnancies were ended with abortus. Six (31.6\%) of the pregnants who used only LMWH during pregnancy had live-birth, whereas $13(68.4 \%)$ had abortions. In only LDA treatment group $8(72.7 \%)$ had live birth, however 3 (27.3\%) had abortions (Table 2). When LDA+LMWH treatment was compared with only LMWH or only LDA group, live-birth ratio was significantly higher in LDA+LWH group [88(77.8\%) and $14(46.6 \%), \mathrm{p}=0.001]$. The live birth ratios of PrimRSA and SecRSA groups were given in Table 3. In SecRSA group women had significantly higher live-birth rates irrespective to the treatment modality [62/75(82.6\%) and 40/68(58.8\%), $\mathrm{p}=0.002]$

Table 2. Pregnancy outcome frequencies according to treatment modality

\begin{tabular}{llllll}
\hline \multirow{2}{*}{$\begin{array}{l}\text { Treatment } \\
\text { modality }\end{array}$} & \multicolumn{5}{c}{ Pregnancy outcome, $\mathbf{n}(\%)$} \\
\cline { 2 - 5 } & $\begin{array}{l}\text { Early } \\
\text { abortus }\end{array}$ & $\begin{array}{l}\text { Late } \\
\text { abortus }\end{array}$ & $\begin{array}{l}\text { Live } \\
\text { birth }\end{array}$ & $\begin{array}{l}\text { Preterm } \\
\text { delivery }\end{array}$ & Total \\
\hline Only LDA & $3(27.3)$ & 0 & $7(63.6)$ & $1(9.1)$ & 11 \\
Only LMWH & $11(57.9)$ & $2(10.5)$ & $6(31.6)$ & 0 & 19 \\
LMWH+LAD & $23(20.3)$ & $2(2.1)$ & $84(73.4)$ & $4(4.2)$ & 113 \\
Total & 36 & 4 & 76 & 5 & 143 \\
\hline
\end{tabular}

LDA: Low-dose aspirin, LMWH: Low-molecular weight heparin
Grous: Secondary RSA

Figure 1. Miscarriage and Livebirth rates in Primary RSAs (recurrent spontaneous aborters) and Secondary RSAs according to treatment modality
Table 3. Live-birth and pregnancy loss rates in PrimRSA and SecRSA groups, and in treatment modality groups, $n$ (\%)

\begin{tabular}{|c|c|c|c|}
\hline & Pregnancy Loss & Live-birth & $\mathbf{p}$ \\
\hline \multicolumn{4}{|l|}{ Group } \\
\hline PrimRSA & $28 / 68$ (41.2) & $40 / 68$ (58.8) & \multirow{2}{*}{0.002} \\
\hline SecRSA & 13/75 (17.4) & 62/75 (82.6) & \\
\hline \multicolumn{4}{|c|}{ Treatment Modality } \\
\hline Only LDA/ & $16 / 30(53.3)$ & $14 / 30(46.7)$ & \multirow{3}{*}{0.01} \\
\hline only LWH & & & \\
\hline $\mathrm{LDA}+\mathrm{LWH}$ & 25/113 (22.1) & 88/113 (77.9) & \\
\hline
\end{tabular}

LDA: low-dose aspirin, LMWH: low-molecular weight heparin. p: chi-square test

\section{DISCUSSION}

In this study we reported a review of 143 pregnant women who had recurrent pregnancy loss and genetic trombophilia mutations. We reported that early pregnancy miscarriages were much more frequent than late pregnancy loss in both PrimRSA and SecRSA groups. Approximately three-fourths (72.1\%) of PrimRSAs and two-thirds $(66.6 \%)$ of SecRSAs had three or more positive genetic mutation for trombophilia. Live birth ratios were significantly higher in SecRSAs than PrimRSAs. Moreover, combined treatment with low dose aspirin and low-molecular weight heparin during pregnancy significantly increased livebirth rates in both groups compared to the treatment only with LDA or LMWH.

Inflammation and coagulation disorders are proposed to have important role in the pathogenesis of 
recurrent pregnancy loss [10]. For successful implantation of the blastocyst the presence of sterile inflammation is needed [11]. In the case of increased natural killer cells in uterine tissue, cytokine secretion is endorsed causing embryo loss due to ischemia or thrombophilia activated by endothelia cell-procoagulants.

The history of previous recurrent pregnancy loss was shown to be a risk factor for the subsequent pregnancies [12]. In a study natural killer (NK) cellnumbers and NKA activity were compared between PrimRSAs, SecRSAs and control healthy women [13]. In this study it was reported that primary aborters had significantly higher NKA than did either secondary aborters or control women [13]. However the number of miscarriages were higher in SecRSAs than primary aborters [13]. In our study there were no differences between median number of total pregnancies between primary and secondary aborters. Pregnants in both group experienced miscarriages more in the early pregnancy period.

The role of hereditary trombophilia on recurrent miscarriages is controversial. In some studies, the prevalence of some or all trombophilias were reported to be increased [14-16] and others did not present any increased prevalence $[17,18]$. The presence of co-existent inherited trombophilia markers during pregnancy are reported to increase the risk of thrombosis [19]. Lenz B reported that combination of FVL and MTHFR mutation was related to the risk of recurrent fetal death and habitual abortion [20]. In our study $72.1 \%$ of the primary and $66.6 \%$ of the secondary aborters had three or more co-existent thrombophilia gene mutations. There were no difference in the prevalence of thrombophilia genes and the number of co-existence in between two groups.

Clinical studies were conducted on the treatment of pregnant women with thrombophilia to achieve the best pregnancy outcomes. Mainly immunomodulators, low dose aspirin and low molecular weight heparin were used. In the study of De Carolis et al. LMWH use in patients with hereditary thrombophilia improved number of live births, increased birth weights, and decreased perinatal complications [21]. Brenner et al. also reported that LMWH use improved live birth rates [22]. Low dose aspirin has also been compared with LMWH. Giancotti et al. reported that LMWH or LMWH + LDA combination therapy is significantly more protective against fetal losses than LDA-only treatment [23]. They also recommend thromboprophylaxis for women with histories of RPL, without considering the positiveness of thrombophilic markers. Carp et al. reported that enoxaparin use prevents further pregnancy losses in patients with hereditary trombophilias and recurrent miscarriages [24]. In their study, the main effect of enoxaparin use was mainly seen in primary aborters with a $42 \%$ improvement in livebirth, whereas $8 \%$ improvement in livebirth rate in secondary aborters was seen. In another study the combination of LDA and LMWH is suggested to give better results than LDA alone for the maintenance of pregnancy in patients with recurrent first trimester miscarriage [25], similar to our results. In our study , the combination of LDA+LMWH for the treatment of pregnants with recurrent spontaneous abortions and thrombophilia improved livebirth rates better than only LDA or only LMWH use. Differently in our study the livebirth rates were much higher in SecRSAs than PrimRSAs. Mutlu I et al. also concluded that anticoagulant therapy with both LMWH and LDA seems to provide better obstetric outcomes in pregnant women with thrombophilia and previous poor obstetric outcomes [26]. We suggest that in women with coexistent inherited thrombophilia and recurrent miscarriages thromboprophylaxis is more effective.

Complete thrombophilia work is both complicated and costly. Since the association between thrombophilia and adverse pregnancy outcomes vary in different populations, new and better screening tools need to be developed and better defined populations at risk for adverse pregnancy outcomes should be established.

In conclusion, thromboprophylaxis improves livebirth rates in women with recurrent aborters. The strength of this study is that we studied the pregnant women with RPL and at least two positive genetic thrombophilia mutation. Moreover this study evaluated the effect of thromboprophylaxis treatment in both primary and secondary aborters. We detected that having at least one previous livebirth is a good prognostic factor and these secondary aborters got more benefit from $\mathrm{LMWH}+\mathrm{LDA}$. The weakness in this study is that it is not a prospective randomized controlled trial, but it is a retrospective study. Future prospective studies with lager samples should be performed to prevent adverse pregnancy outcomes in women with recurrent abortus and thrombophilic defects.

Acknowledgements: We thank to laboratory staffs at Mevlana University Hospital.

Declaration of Conflicting Interests: The authors declare that they have no conflict of interest. 
Financial Disclosure: No financial support was received.

\section{REFERENCES}

1. Beak KH, Lee EJ, Kim YS. Recurrent pregnancy loss: the key potential mechanisms. Trends Mol Med 2007;13:310317.

2. Carson A, Branch W. Management of recurrent early pregnancy loss, Compendium selected publications. American College of Obstetricians and Gynecologists, Washington, DC, 2000:372-383.

3. Sarig G, Klil-Drori A.J, Chap-Marshak D, et al. Activation of coagulation in amniotic fluid during normal human pregnancy. Thromb Res 2011;128:490-495.

4. Szecsi, P.B, Jorgensen M, Klajnbard A, et al. Haemostatic reference intervals in pregnancy. Thromb Haemost 2010;103:718-727.

5. Yokuş O, Balçık Ö.Ş, Albayrak M, et al. Thrombophilic risk factors in women with recurrent abortion. J Clin Exp Invest 2010;1:168-172.

6. Wu O, Robertson L, Twaddle S, et al. Screening for thrombophilia in high-risk situations: a meta-analysis and costeffectiveness analysis. Br J Haematol 2005;131:80-90.

7. Nadar S, Blann AD, Kamath S, et al. Platelet indexes in relation to target organ damage in high-risk hypertensive patients: a substudy of the Anglo-Scandinavian Cardiac Outcomes Trial (ASCOT). J Am Coll Cardiol 2004;44:415422.

8. John H Antiphospholipid syndrome: an overview. Can Med Assoc J 2003;168:1675-1682.

9. Sarig, G., Younis, J. S., Hoffman R., et al. Thrombophilia is common in women with idiopathic pregnancy loss and is associated with late pregnancy wastage. Fertil Steril 2002;77:342-347.

10. Kwak JY, Beer AE, Kim SH, Mantouvalos HP. Immunopathology of the implantation site utilizing monoclonal antibodies to natural killer cells in women with recurrent pregnancy losses. Am J Reprod Immunol 1999;41:91-98.

11. Kwak-Kim J, Yang KM, Gilman-Sachs A. Recurrent pregnancy loss: a disease of inflammation and coagulation. $\mathrm{J}$ Obstet Gynaecol Res 2009;35:609-622.

12. Cauchi MN, Coulam CB, Cowchock S, et al.Predictive factors in recurrent spontaneous aborters--a multicenter study. Am J Reprod Immunol 1995;33:165-170.

13. Shakhar K, Ben-Eliyahu S, Loewenthal R, et al. Differences in number and activity of peripheral natural killer cells in primary versus secondary recurrentmiscarriage. Fertil Steril 2003;80: 368-75.
14. Brenner B, Mandel H, Lanir N, et al. Activated protein C resistance can be associated with recurrent fetal loss. Br J Haematol 1997;97:551-554.

15. Rai R, Shlebak A, Cohen H, et al. Factor V Leiden and acquired activated protein $\mathrm{C}$ resistance among 1000 women with recurrent miscarriage. Hum Reprod 2001;16:961-95.

16. Raziel A, Kornberg Y, Friedler S, et al. Hypercoagulable thrombophilic defects and hyperhomocysteinemia in patients with recurrent pregnancy loss. Am J Reprod Immunol 2001;45:65-71.

17. Holmes ZR, Regan L, Chilcott I, Cohen H. The C677T MTHFR gene mutation is not predictive of risk for recurrent fetal loss. Br J Haematol 1999;105:98-101

18. Carp HJA, Salomon O, Seidman D, et al. Prevalence of genetic markers for thrombophilia in recurrent pregnancy loss. Human Reprod 2002;17:1633-1637.

19. Villanı M, T1scia GL, Margaglione M, et al. Risk of obstetric and thromboembolic complications in family members of women with previous adverse obstetric outcomes carrying common inherited thombophilias. J Thromb Haemostasis 2012;10: 223-228.

20. Lenz B, Samardzija M, Drenjancevic D, et al. The investigation of hereditary and acquired thrombophilia risk factors in the development of complications in pregnancy in Croatian women. J Matern Fetal Neonatal Med 2016;29:264-269.

21. De Carolis S, Ferrazzani S, De Stefano V, et al. Inherited thrombophilia: treatment during pregnancy. Fetal Diagn Ther 2006;21:281-286.

22. Brenner B. Inherited thrombophilia and fetal loss. Curr Opin Hematol 2000;7:290-295.

23. Giancotti A, La Torre R, Spagnuolo A, et al. Efficacy of three different antithrombotic regimens on pregnancy outcome in pregnant women affected by recurrent pregnancy loss. J Matern Fetal Neonatal Med 2012; 25:1191-1194.

24. H. Carp, M. Dolitzkyand, A. Inbal. Thromboprophylaxis improves the live birth rate in women with consecutive recurrent miscarriages and hereditary thrombophilia. J Thromb Haemostasis 2003;1:433-438

25. Elmahashi MO, Elbareg AM, Essadi FM, et al. Low dose aspirin and low-molecular-weight heparin in the treatment of pregnant Libyan women with recurrent miscarriage. BMC Research Notes 2014;7:23.

26. Mutlu I, Mutlu M, Biri A, et al. Effects of anticoagulant therapy on pregnancy outcomes in patients with thrombophilia and previous poor obstetric history. Blood Coagulation \& Fibrinolysis 2016; 26:267-273. 